\title{
Origins, Developments and Future of the Concept of Innovation: Opening the Economic Framing of Innovation to Social, Ethical, Political Parameters to Achieve Responsibility: Strengths and Limits
}

\author{
Laurence Masclet and Philippe Goujon \\ University of Namur, Namur, Belgium \\ laurence.masclet@unamur.be, pgo@info.fundp.ac.be
}

\begin{abstract}
The concept of innovation is making a successful comeback in philosophy, particularly with the qualifier "responsible" attached. This attachment of the qualification "responsible" reflects the idea that the concept of innovation has to be opened to new considerations, namely social, political and ethical concerns. Since the 18th century, innovation has been the object of economics and science of business and growth. This paper aims at testing the legitimacy of these attempts to open the concept and redefine it in terms other than those of economics. We start with a contextualization of the use of the term innovation, to see why it has been so strongly associated with the market, growth and business then we see what is at stake in opening it up to other considerations. We consider the limits of this opening and look at possible ways to attach other meanings to the concept, without losing significance by too much inclusion. The solution proposed is that instead of imposing new parameters and trying to shift the concept, we could keep the economic bias of the term, but challenge it with concerns expressed by people coming from the field of economics who are trying to propose an alternative framework for economics that would take into account other concerns, and in which responsible innovation could find a place.
\end{abstract}

Keywords: Innovation, economy, society, ethics, responsibility.

\section{Introduction}

The concept of innovation is nowadays coming back to fashion with the prefix "responsible" attached to it, to form the phrase "Responsible Innovation" or "Responsible Research Innovation" (RRI) [7,8]. The addition of the specification "responsible" is interesting in many respects. First, it emphasizes that innovation is not, by itself, responsible - hence the need for the specification - and secondly, it seems like the manifestation of a will to broaden the sphere of the analysis of innovation. Indeed, innovation has been the object of economics and the science of business and growth since the 18th century. This paper will try to test the legitimacy of the attempt to open the concept of innovation to other sources of meaning and to other concerns than those of economics. 
The meaning of the concept of responsibility is the object of a vast area of literature, especially in philosophy. We take it here as a broader concept than just legal accountability, as a moral concept $[26,27]$. We will focus here on the "innovation" side of the concept of "responsible innovation", and on the presuppositions that are disclosed by the very use of that expression. The concept of innovation in its broad definition is used in many fields. It is not unusual to talk for example about innovation in art, innovation in teaching, innovation in governance, innovation in war making or car driving. In various fields the term is very often used as a weaker version of the term 'invention', meaning anything bringing something new to a field. It seems to be most frequently attached to technological changes occurring in different fields, but not always.

In the academic world, the term has been one of the main object of economy since the emergence of the field. Schumpeter in 1934 described innovation as "New Combinations" $[16,17]$, and the core of his analyses and framing of the definition of an innovation are still very much unchanged [11] [23].

In this paper, we will give a brief reconstruction of the history of the philosophical concept of innovation, focusing mainly on the major shift in the perception, the field and the use of the concept, in order to try to broaden its limits. Indeed, history shows that this concept is far from univocal, and has been the object of many changes of perception. This tends to validate the idea of trying to open the concept to other meanings than those drawn from economics and technology. Once we have established the freedom to manipulate the concept, we will have to see where the restriction to economics occurs, and what the legitimacy of this restriction is. By doing this, we will made apparent some limits to the idea of another shift of the concept to reach responsible innovation, and we will have to find compromises between the intrinsic economic bias of the concept and the need to open it to other preoccupations.

\section{History of the Concept}

The first occurrences of the notion of innovation are very different from current usage. Indeed, innovation, from it first use until the $18^{\text {th }}$ century was used as a strongly derogatory term.

"Innovation", from the Latin innovare, innovation, should signify renewal, rejuvenation from inside, rather than novelty, which is its modern meaning in both English and French. Judging from the examples in the Oxford English Dictionary and the Littré, the word came into widespread use only in the 16th century and, until the 18th century, its connotations are almost uniformly unfavorable.’[5]

This negative bias is a result of innovation's original connection to theology. An innovation from a theological dogma is never considered to be progress. On the contrary, being innovative in the context of religion is regarded has a direct way to heresy. 
The negative sense of the word innovation also occurs in political sciences, in which it is linked to rebellion and revolution, and is shared even among thinkers who we would call innovators today. The paradox is that even reformers like Calvin saw innovation as a bad thing, because the aim of the reformation was not to create something new, but to come back to the original ideal of Christianity. And the Humanists, after the Protestants, despised innovation as well, advocating a return to the ideas and models of classical antiquity [5].

Despite Girard's interpretation of what innovation "should" signify - i.e. "renewal, rejuvenation from inside" [5]- this is not really how it has been interpreted, otherwise the Reformation would have been branded as an innovation for example, which it wasn't. It is only during the $18^{\text {th }}$ century that the notion started to take on a more positive meaning, corresponding to a shift in society. The word was increasingly detached from theology and was instead attached to technological development and economic growth. In the $18^{\text {th }}$ century and later during the $19^{\text {th }}$ century and the industrial revolution [25], the notion of innovation became used to mean the imitation and improvement of an invention in a field. Indeed, in the commercial and industrial fields it has never been enough to invent something new (new methods, new products, etc.): improvements always immediately connected to commercialization. And innovation seems to be associated with this commercial aspect of an invention, and its imitation and improvement by the competition, creating a chain of development that can revolutionize a field without needing properly new products or methods, but rather through improvements of ideas from one industry to the next, in a mechanism economists call "incremental innovation".

Invention in itself seems to be already connected to commercialization in most cases, so it is difficult to argue that innovation is only the commercial side of invention. It is much more significant to say that innovation distinguishes itself from invention by its incremental characteristics. ${ }^{1}$

We have briefly sketched the history of innovation as a concept, and seen that this history was marked by a major switch that corresponds to a major change of focus in society $^{2}$ from theology to economics. However, we have seen that nowadays, the concept of innovation is also used in other fields and has become part of vernacular language and popular culture. It is also more and more linked with the adjective "responsible" [19] [8] in an attempt to include other considerations (ethical, social, political) than those of economics ${ }^{3}$. But is this extension possible and legitimate?

1 How then can we talk about "radical" innovation is another research question that we will have to develop in further researches.

2 Although, of course, this change of focus in society did not happened over night, and there are a lot of discussions to be made on when and where (or indeed whether) this change happened.

3 The question of the meaning and legitimacy of adding such a qualifier -thus implying that innovation is not/cannot be responsible per se-will also be the object of further researches and cannot be developed here. 


\section{Opening the Sphere of Meaning (and Limits)}

\subsection{Innovation as "New Combinations"}

Joseph Schumpeter (1883-1950) was the first theorist to make the distinction between the concept of innovation and the concept of invention, and to define innovation as a first commercial transaction successfully achieved [1]. By this definition, Schumpeter links in the collective consciousness the notions of innovation, of commercialization and of technical objects. Schumpeter's framework is still being discussed today, and, although of course challenged on many points [2], it is still a general reference point for anybody who wants to tackle the subject of innovation or entrepreneurship [23] ${ }^{4}$. Schumpeter defined innovation as "the setting up of a new production function" or "New Combinations", which relate to incremental innovation we referred to above.

"We will now define innovation more rigorously by means of the production function previously introduced. This function describes the way in which quantity of product varies if quantities of factors vary. If, instead of quantities of factors, we vary the form of the function, we have an innovation. But this not only limits us, at first blush at least, to the case in which the innovation consists in producing the same kind of product that had been produced before by the same kind of means of production that had been used before, but also raises more delicate questions. Therefore, we will simply define innovation as the setting up of a new production function. This covers the case of a new commodity, as well as those of a new form of organization such as a merger, of the opening up of new markets, and so on. Recalling that production in the economic sense is nothing but combining productive services, we may express the same thing by saying that innovation combines factors in a new way, or that it consists in carrying out New Combinations, although, taken literally, the latter phrases would also include what we do not now mean to include -namely, those current adaptations of the coefficients of production which are part and parcel of the most ordinary run of economic routine within given production functions." [16].

This very economical way of defining innovation has been very influential but is in fact the heir of the $18^{\text {th }}$ century's conception of innovation and its primary link to technological invention, commercialization, industrial concurrence and general growth. This way of looking at innovation as "setting up of new production functions" seems to be very narrowly economic, and, as a side effect, seems to put aside any consideration other than the need for growth and novelty for its own (economic) sake.

\footnotetext{
${ }^{4}$ For example : "Of all the theories of entrepreneurship that exist, his theory is still, to my mind, the most fascinating as well as the most promising theory of entrepreneurship that we have. Let me clarify. I do not argue that Schumpeter's theory, as it is understood today, can supply the key to the mystery of entrepreneurship. What I would like to suggest, however, and also devote this paper to, is the argument that it may well constitute the point of departure for the development of the theory of entrepreneurship." [23]
} 
The combination between the increasingly ubiquitous nature of the concept of innovation nowadays, and its bias towards economics is problematic in the sense that it spreads its unquestioned presuppositions and strengthens the domination of economic thinking in society ${ }^{5}$. So there is a benefit in opening the concept of innovation, as the pursuit of innovation has massive impacts on society as a whole. If legislators act as innovators, it seems reasonable to demand that they seek ways to make innovations more responsible, more ethical and socially and environmentally aware, as well as to stifle innovations that have unethical impact on society ${ }^{6}$. Many theories of governance and research projects have investigated ways of opening the framework of innovation to include more contextual parameters into the conception of an innovation and more generally, into decisions to start to research a potential innovation VOICES $^{7}$, PROGRESS [20], ETICA ${ }^{8}$, Responsibility ${ }^{9}$, GREAT $^{10}$, to quote a few, which are all funded either on the $7^{\text {th }}$ framework Programme (FP7) or Horizon 2020 from the European Commission).

However, we are trying to find out here if the concept of innovation is ready to be opened to other spheres of meaning. Regarding the history of the concept, we can see that it is very much open to shifts in both meaning and fields of application, even though it is always connected throughout history with two features :the first is the notion of novelty (whether this is considered as a good thing or not) and secondly, it is always interpreted in relation to the most powerful and influential field in society (theological when theology was the most powerful force shaping society, and economic when economics was defining the aims of society).

The stakes are high because succeeding in transforming the mechanisms of innovation in order to make it more ethical would imply a shift towards a more ethical society. But this reasoning is of course bad logic, because the opposite is more probable: only a shift in society towards more responsible behaviour will change innovation.

The history of the concept of innovation also shows us the potential for inclusion that this notion entails. Indeed, if we take Schumpeter's definition of innovation as "New Combinations", it is very open to all sorts of spheres and material for combinations.

5 The dominance of some economic ways of thinking cannot be reduced to the increasing use of the term innovation of course. The causal relation is probably reversed: it is the dominance of economic jargon that enhance the general use of the term innovation. But even if that is true, it is still an ethical and social worry to find economic terms carrier of so many economic presuppositions being used for daily conversation. The same can be said about many economic words that have invaded the public and private spheres.

${ }^{6}$ For more on this question on the ways to achieve responsible innovation, see for example the ongoing « Governance for Responsible Innovation" (GREAT) Project.

http: / / www.great-project.eu/

7 (Views, Opinions and Ideas of Citizens in Europe on Science

http: / / www . voicesforinnovation.eu/).

${ }^{8}$ ETICA : Ethical Issues of Emerging ICT Applications, project funded under FP7.

9 Global Model and Observatory for International Responsible Research and Innovation Coordination http://responsibility-rri.eu/

${ }^{10}$ Governance for Responsible Innovation. http: / / www.great-project.eu/. GREAT develop an empirically based and theoretically sound model of the role of responsible research and innovation governance and is funded under Horizon 2020. 
Schumpeter reduces it to economics, but the reduction is not in the material of innovation but in its aims. Innovation's material (the things being reassembled into new combinations) is open to anything as long as they are being commercialized and contribute to economic development.

Does the opening to ethics and responsibility imply that we have to leave out the economic aims of innovation or that we have to make new combinations with other parameters than the ones usually used? It seems that it is the commercial aims that are at stake if we want to achieve responsible innovation, maybe not by removing completely its commercial side, but certainly by adding new aims, like constructing a more ethical and safe society. The limitation of thinking of innovation as New Combinations and opening its aims to other goals, is the danger that it becomes meaningless by including everything in it. Indeed, if we are talking about new combinations of any material (as Schumpeter's definition allows) without the restriction of economic aims, we could argue that any thought, any action is an innovation, as it is a new combination of existing elements [14] [15]. Language is the perfect example of new combinations. From a limited stock of words, human beings is able to produce unlimited texts, conversation, ideas and stories. Yet, we cannot consider any text or any conversation or any thought to be an innovation. There seems to be something more to it, otherwise it loses all meaning. If innovation material is open to anything, the restriction needed seems to be in the economic impact expected from it ${ }^{11}$.

We could argue that random conversation or though can potentially be exploited economically, but the point is that it is only then, when economic exploitation is sought, that ideas become innovation. Before commercial aims, an idea cannot be considered yet an innovation.

\subsection{Consequences of the Inherent Link between Innovation and Economics}

We talked about the political and social will to make innovation more responsible and thus, opened it to new spheres of meaning and other concerns than mere economics and growth. But the definition of the concept of economics, as we argue, ask for an economical restriction to the concept, which is defined by its commercial goal.

So, if we want to open innovation to new spheres of meaning, new parameters and new aims, we have to retain a sufficiently determinate framing in order for the concept to stay meaningful. It does not seem plausible to achieve responsible innovation by situating it outside of economic discourse altogether. However, there are many ways of doing economics, and many economists in the 20th and 21st centuries are making efforts and developing new ways to include other concerns and aims -social fairness, redistribution, ethics, political stability, etc.- than mere economic growth ${ }^{12}$ $[28,29,30,31,32]$. Alternative economic framings exist that take into account

${ }^{11}$ Whether or not these commercial aims are met is not relevant to qualify an innovation as such. The commercial aims themselves (added to the novelty of the combination) seems to be sufficient as a criterion for innovation.

${ }^{12}$ For example Amartya Sen, or on another level the current school of degrowth, like the The Club of Rome, Nicholas Georgescu-Roegen, Serge Latouche in France, Christian Arnsperger and Philippe Van Parijs in Belgium or even Marxist theorists. 
contextual and ethical parameters within their conception, and responsible innovation seems to fit into this way of thinking. The task for philosophers remains to evaluate whether in those theories the economic framing that seems to be impossible to remove does not contaminate and reinterpret other concerns so much that they become themselves economic. This idea of contamination can be seen for example in the dynamic of trying to «sell » ethics as a « good commercial move » for companies (in term of image, long-term benefits, or saving by pre-empting potential social rejection ${ }^{13}$ ), or in the way of promoting art subventions as investments and potentiality to create growth, rather than for art itself, etc.

To achieve the challenge of putting responsibility into innovation, we cannot impose a new framing on the concept of innovation and impose a change of field. We cannot open it to the extent it becomes meaningless, but should find, within the conception of the notion itself, the openings that can be reached without reducing alternative aims to another economic framing.

The Information and Communication Technologies (ICT) field is an important sector of innovation and has been also the object of ethical concerns over the years [22]. The technological angle in innovation is as powerful as the economic angle, and is therefore responsible for restriction within the concept of innovation, which is not completely in phase with the will to open the concept. However, the same conclusion could be made for technology as it has been made for economics: it seems impossible to leave out the technological understanding of innovation. However, it does not mean that innovation is restricted to technological innovation, and moreover, that technological innovation are only technology. What the concept of responsible innovation tends to achieve is on the contrary to drive technical innovation toward other field of concerns outside mere technology or economy.

Even if the field of ICT is particular in many respects (treating which such a peculiar and ubiquitous object that is information [10]), the idea of opening the sphere of meaning of innovation has an identical application. In order to impose responsibility into innovation in ICT, one should not need to evacuate the economical bias implanted within the notion of innovation -basically innovation as a necessity for business to survive among competitors and for society to raise growth. On the contrary, the economic bias has to be thought of and evaluate for what it is, both what is driving innovation and the criterion by which it is judge. To add another principle, the principle of responsibility, to assess a technology, we have to be prepare to change our perspectives on economic benefits and on the type of economy we want for society.

\section{Conclusion}

Our brief reconstruction of some of the steps of the history of the meaning of innovation has shown us that this concept is both a carrier of huge presuppositions (attachment to economics, to economic growth, to technological development, and so on),

${ }^{13}$ Which is not to say that there is no good argument for ethics as a sustainable investment for companies, but making it the only argument seems to miss the real meaning of ethical concern, and would imply that, in absence of commercial potential, ethics would not be worth pursuing. It is the dynamic behind the argument that is criticized here. 
and still very open to new meanings and very flexible. The only thing that seems to not be detachable from this concept without it losing all meaning is the very thing that has to be carefully managed if we take upon the task of making innovation "responsible": its attachment to economics. Indeed, without an economic connotation, the concept loses signification, and with it, it carries the risk of being blind to any other aspects of society and human life.

But the task of reaching for responsible innovation is not impossible, even from within the field of Economics. Indeed, there are a lot of "alternative" economic theories that aim exactly at this. In fact, the case might be made that most economic theories are aiming towards ethical and social progress and balance, and that some of the blindness in economics are more of a drift from the main aim of economics than an inherent feature of the field. The conceptual linkage between innovation, technology and economy is strong and the challenge of Responsible Innovation, taking responsibility in its full ethical sense and trying to inject it into innovation, has to face the history of its object and address in a fully reflexive way the presuppositions that are embedded in it.

\section{References}

1. Akrich, M., Callon, M., et Latour, B.: A quoi tient le succès des innovations? Annales des Mines 11, 4-17 (1988)

2. Taylor Cromer, C., Dibrell, C., Craig, J.B.: A study of Schumpterian (radical) vs. Kirznerian (incremental) innovations in knowledge intensive industries. Journal of Strategic Innovation and Sustainability 7(1), 28-42 (2011)

3. Chesbrough, H.: Open Innovation: the New Imperative for Creating and Profiting from Technology. Harvard Business School Press, Boston (2003)

4. Guchet, X.: Les Sens de l'évolution technique. Léo Scheer, Paris (2005)

5. Girard, R.: Innovation and Repetition. SubStance, Issue 62/63: Special Issue: Thought and Novation 19(2/3), 7-20 (1990)

6. Hilaire-Pérez, L., Thébaud-Sorger, M.: Les techniques dans l'espace public, Publicité des inventions et littératures d'usage au XVIIIe siècle (France, Angleterre). Revue de Synthèse, 5e série 2006(2), 393-428 (2006)

7. European Commission. Council Decision establishing the Specific Programme implementing Horizon 2020 -The Framework Programme for Research and Innovation (2014-2015), ch. 17. Science with and for Society, Version 1.0. 9 (2013)

8. European Union, Horizon 2020, Work Programme 2014-2015, ch. 16, Science with and for Society, European Commission Decision C (2013) 8631 (2013)

9. European Union, Responsible Research and Innovation, Europe's ability to respond to societal challenges (2012), http : / ec . europa . eu/research/

science-society/index. cfm? fuseaction=public.topic\&id=1622 (retrieved in February 2014)

10. Masclet, L., Goujon, P.: Implementing Ethics in IS, presuppositions and consequences in ethics and IS. In: Hercheui, M.D., Whitehouse, D., McIver Jr., W., Phahlamohlaka, J. (eds.) HCC10 2012. IFIP AICT, vol. 386, pp. 287-298. Springer, Heidelberg (2012)

11. McCraw, T.: Prophet of innovation: Joseph Schumpeter and Creative Destruction. Belknap Press of Harvard University Press, Cambridge (2007) 
12. McDonald, C.: Penserl'invention. Étudesfrançaises 26(3), 101-109 (1990), http://id.erudit.org/iderudit/035828ar (retrieved September 18, 2013)

13. Pestre, D.: A contre-science, Politiques et savoirs des sociétés contemporaines, Paris, Seuil (2013)

14. Schlanger, J.: Penser la bouche pleine. Librairie Arthème Fayard, Paris $(1975,1983)$

15. Schlanger, J.: L'Invention intellectuelle. Librairie Arthème Fayard, Paris (1983)

16. Schumpeter, J.: Business Cycles, A Theoritical, Historical and Statistical Analysisof the Capitalist Process. McGraw-Hill Book Company, New York (1939)

17. Schumpeter, J.: The Theory of Economic Development: An Inquiry Into Profits, Capital, Credit, Interest, and the Business Cycle. Transaction Publisher, New Brunswick (1986); (first edition: Harvard University Press, Cambridge, MA, 1934)

18. O’Sullivan, D., Dooley, L.: Applying Innovation. Sage Publication, Inc., Thousand Oaks (2009)

19. Owen, R., Heintz, M., Bessant, J.: Responsible Innovation, Managing the Responsible Emergence of Science and Innovation in Society. John Wiley, London (2013)

20. Schrempf, B., Kaplan, D., Schroeder, D.: National, Regional, and Sectoral Systems of Innovation - An overview, Report for FP7 Project "Progress", progressproject.eu (2013)

21. Schutte, C., Marais, S.: The Development of Open Innovation Models to Assist the Innovation Process. University of Stellenbosch, South Africa (2010)

22. Stahl, B.: Responsible research and innovation in information systems. European Journal of information Systems 21, 207-211 (2012)

23. Swedberg, R.: Rebuilding Schumpeter's Theory of Entrepreneurship. In: Conference on Marshall, Schumpeter and Social Science. Hitotsubashi University (2007)

24. Veugelers, R.: How to Turn on the Innovation Growth Machine in Europe. In: Metaforum Leuven, Interdisciplinary Think-thank for Societal Debate, Leuven (June 2013)

25. Verley, P.: La révolution industrielle, Coll. Folio Histoire, Gallimard, Paris (2010)

26. Ricoeur, P., Ricoeur, P.: Oneself as Another. The University of Chicago Press, Chicago (1992)

27. Jonas, H.: The Imperative of Responsibility: In Search of an Ethics for the Technological Age. The University of Chicago Press, Chicago (1984)

28. Latouche, S.: Survivre au développement, De la décolonisation de l'imaginaire économique à la construction d'une société alternative. Arthème Fayard (2004)

29. Sen, A.: On economics inequality. Oxford University Press, Oxford (1973)

30. Okan, K., Pamukcu, T.: Innovation Capability for Development: An attempt to apply Amartya Sen's Capability Approach to Innovation Studies. In: 8th Annual Conference of the HDCA, The Hague, The Netherlands, September 6-8 (2011)

31. Arnsperger, C.: Critique de l'existence capitaliste: Pour une éthique existentielle de l'économie. Edition du Cerf, Paris (2005)

32. Georgescu-Roegen, N.: Energy and Economic Myths: Institutional and Analytical Economic Essays. Pergamon Press, New York (1976) 